\title{
Evaluation of in vitro Antiviral Activity of Essential Oil Compounds Against Dengue Virus
}

\author{
María C. Flechas, Raquel E. Ocazionez*, Elena E. Stashenko
}

\section{María C. Flechas, Raquel E. Ocazionez*, Elena E. Stashenko}

Centro de Investigaciones en Enfermedades Tropicales (CINTROP) and Centro de Investigación en Biomoléculas (CIBIMOL), Universidad Industrial de Santander, Bucaramanga, COLOMBIA.

Correspondence

Raquel E Ocazionez

Universidad Industrial de Santander, CINTROP, Guatiguará, Km2 Autopista Bogotá, via Refugio, Piedecuesta, Santander, COLOMBIA.

Phone no: 57-7-634400-3585

E-mail: relocaz@uis.edu.co

\section{History}

- Submission Date: 12-07-2017;

- Review completed: 31-07-2017.

- Accepted Date: 21-08-2017

DOI : 10.5530/pj.2018.1.11

Article Available online http://www.phcogj.com/v10/i1

\section{Copyright}

(C) 2018 Phcog.Net. This is an openaccess article distributed under the terms of the Creative Commons Attribution 4.0 International license.

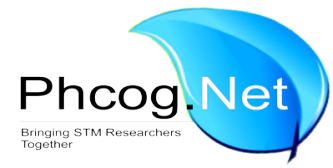

\begin{abstract}
Introduction: There are not effective drugs available for treatment of dengue fever despite intensive research on synthetic inhibitors. The search for active phytochemicals could serve for the discovery of new drugs. This study aims to evaluate the antiviral activity in vitro of compounds found in essential oils from medicinal plants. Materials and Methods: Nine synthetic-derived essential oil compounds were evaluated. Antiviral effect was screened measuring the reduction of viral NS1 and E proteins in HepG-2 and Vero cells. Results: $\beta$-Caryophyllene was identified as the most active compound, it reduced the virus serotype-2 replication in HepG-2 cells at $I C_{50}$ of $22 \pm 5.6 \mu \mathrm{M}$, and blocked replication of all four serotypes in Vero cells at $\mathrm{IC}_{50}$ between $8.0 \mu \mathrm{M}$ and $15.0 \mu \mathrm{M}$. The selectivity indexes were between 5.3 and 10. According to results from time-in-addition assays, the antiviral effect of $\beta$-caryophyllene appears to be associated with interruption of early steps of the virus life cycle. Citral revealed modest antiviral effect, it reduced the virus serotype-2 $\left(\mathrm{IC}_{50}\right.$ of $\left.31 \pm 4.5 \mu \mathrm{M}\right)$ replication but not the other three serotypes. Seven terpenes did not reveal antiviral activity at maximum concentration of $30 \mu \mathrm{M}$. Conclusion: Research on compounds found in essential oils can contribute to the drug discovery effort for dengue. $\beta$-Caryophyllene could serve as a starting point. Key words: Terpene, Essential oil, Dengue, Antiviral, Flavivirus.
\end{abstract}

\section{INTRODUCTION}

Dengue is caused by four antigenically related serotypes of dengue viruses (DENV-1, DENV-2, DENV-3 and DENV-4), which belong to the genus Flavivirus. ${ }^{1}$ There were an estimated of 58.4 million symptomatic dengue infections in 141 endemic countries in 2013 (13,586 fatal cases), and the total cost of illness was estimated in US \$ 8.9 billion. $^{2}$ No effective drugs exist to treat dengue infections, the current treatment is limited to fluid therapy and supportive care. ${ }^{3}$ Treatment could be insufficient and lead to mortality in patients with severe disease. Drug discovery for dengue has focused on synthetic molecules targeting host and virus proteins. Numerous inhibitors with various modes of action have been discovered and several of them showed efficacy in rodent models. ${ }^{4,5} \mathrm{~A}$ few molecules have advanced to a clinical trial but none so far has yielded encouraging results. Recent proof-of-concept clinical trials have been performed using approved drugs, they also showed lack of efficacy. ${ }^{5,6}$ Search for effective and lower cost therapeutic agents remains of highest importance. Products obtained from medicinal plants represent a rich sources of molecules with therapeutic potential in the search for novel anti-DENV drugs. ${ }^{7,8,9,10}$ Plants produce essential oils as secondary metabolites, which are known as natural antimicrobials and often cited as anti-inflammatories. ${ }^{11}$ Several reports have demonstrated antiviral activity of essen- tial oils against Flavivirus. ${ }^{8,9,12,13,14,15}$ Essential oils are a mixture of high chemical diversity and biochemical specificity of compounds, which belong to different classes of chemicals. The main class include terpenes, phenylpropanoids, and short-chain aliphatic hydrocarbon derivatives, being responsible for their biological activities. ${ }^{16}$

The terpenes and terpenoids are the most representative components present in almost all essential oils and have a great variety of structures. There is an increasing interest on these compounds because of their antimicrobial, antitumoral and anti-inflammatory properties. ${ }^{17,18,19}$ Thus, terpenes and terpenoids offer a great opportunity to find novel lead molecules with specific inhibitory mechanisms on DENV. Antiviral activity of terpenes against Flavivirus have been demonstrated: citral blocked the Yellow-Fever Virus replication in vitro, ${ }^{15}$ and treatment with combined monoterpenes delayed morbidity of mice due to West Nile Virus infection. ${ }^{20}$ There is no report about antiviral potential of essential oils compound on DENV.

The present study aimed to evaluate the antiviral activity of synthetic-derived compounds on DENV, which are main constituents of essential oils that revealed anti-dengue activity in previous studies. ${ }^{8,12,13}$ 
A cell-based assay-guided screening approach was followed to identify the strongest active compound.

\section{MATERIALS AND METHODS}

\section{Compounds}

Nine synthetic-derived essential oils compounds were selected: $\beta$-caryophyllene, citral, (R)- (-)-carvone, (S)-(+)-carvone, (R)-(+)-limonene, $\rho$-cymene, geranyl acetate, nerol, and $\alpha$-phellandrene. Structural formulas are presented in Figure 1. Ribavirin was applied as reference antiviral drug. All compounds met high purity standards, they were purchased from Sigma-Aldrich (St. Louis, MO, USA). Compounds were dissolved in dimethyl sulfoxide and further diluted in medium for cell culture, resulting in dimethyl sulfoxide concentration below $1 \%$ which has no effect on cells and viruses' viability.

\section{Cells and virus}

HepG-2 cells (from human liver, hepatocellular carcinoma, ATCC HB-8065 ${ }^{\mathrm{TM}}$ ) were cultured in DMEM/F-12 medium (Gibco) supplemented with $10 \%(\mathrm{v} / \mathrm{v})$ fetal calf serum (FCS) and $1 \%$ penicillin (100 $\mathrm{U} / \mathrm{ml}$ ) /streptomycin $(100 \mathrm{mg} / \mathrm{ml}$ ) solution (Gibco). Vero cells (from kidney of African green monkey; ATTCC ${ }^{\oplus}$ CCL- $\left.81^{\text {ma }}\right)$ were cultured in MEM medium (Gibco) supplemented with $8 \%(\mathrm{v} / \mathrm{v})$ FCS and antibiotics. DENV-1 (Hawaii strain), DENV-2 (NGC strain), DENV-3 (H-87 strain), and DENV-4 (H-241 strain) viruses were propagated in Aedes alboptictus mosquito cells (clone C6/36).

\section{Viral non-structural 1 (NS1) protein reduction assay}

HepG-2 cells were used. Multiplicities of infection (MOI: 0.06, 0.13, 0.25, 0.5 , and 1.0 ) were tested to find the optimal proportion of virus for cellular infection. MOI of 1.0 was used for subsequent experiments. DENV-2 was adsorbed $1 \mathrm{~h}$ onto cells grown in 96 well plates, the virus inoculum was aspirated and the monolayer was rinsed. Culture medium containing the test compound $(1,5,25$, and $100 \mu \mathrm{M})$ was added and virus replication was allowed for $72 \mathrm{~h}$. Controls were run in parallel and included cells either uninfected or virus-infected in the absence of terpene. The $\mathrm{IC}_{50}$ value, which is defined as the compound concentration that is required to reduce viral NS1 protein by $50 \%$ relative to the untreated control cells ( $0 \%$ reduction), was determined using logarithmic interpolation.

\section{In situ, cellular enzyme-linked immunosorbent (ELISA) assay}

A modified protocol of the microneutralization assay described by Vorndam and Beltran was followed. ${ }^{21}$ For optimization, MOIs of 1- 0.0003 for each virus serotype were tested using ribavirin. Briefly, DENV (MOI of 0.5) was adsorbed $1 \mathrm{~h}$ on Vero cells seeded into a 96-well plate, compound was added at non-toxic concentration range $(1,10,30$, and $50 \mu \mathrm{M})$ in triplicate, and the plate was incubated at $37^{\circ} \mathrm{C}$. Controls (cells either uninfected or virus-infected in the absence of compound) were also run in parallel in every assay plate. After 5 days of incubation, the cells were fixed with a 1:1 methanol: ethanol solution for $30 \mathrm{~min}$ at $-20^{\circ} \mathrm{C}$, and the plates were washed five times with washing buffer. The ELISA was performed by adding anti-DENV MAB 4G2 antibody (CDC, Puerto Rico) $2 \mathrm{~h}$ at $37^{\circ} \mathrm{C}$, followed by the secondary antibody goat anti-mouse IgG HRP (Kirkegaard and Perry, Gaithersberg, USA) for 1 h at the same temperature. Plates were washed, and ABTS substrate solution (Kirkegaard and Perry) was added (1h). The optical density (OD) was measured at $405 \mathrm{~nm}$ in a microplate reader (MultiskanGo, Thermo Fischer Scientific, USA). The $\mathrm{IC}_{50}$ value was determined using logarithmic interpolation.

\section{MTT assay}

Decrease of cell viability was examined on cell lines (HepG-2 and Vero) in which the antiviral activity was evaluated. Cells seeded in 96-well plates were exposed to a concentration range $(10-1600 \mu \mathrm{M})$ of compound for $72 \mathrm{~h}$ at $37^{\circ} \mathrm{C}$. The culture medium was removed and

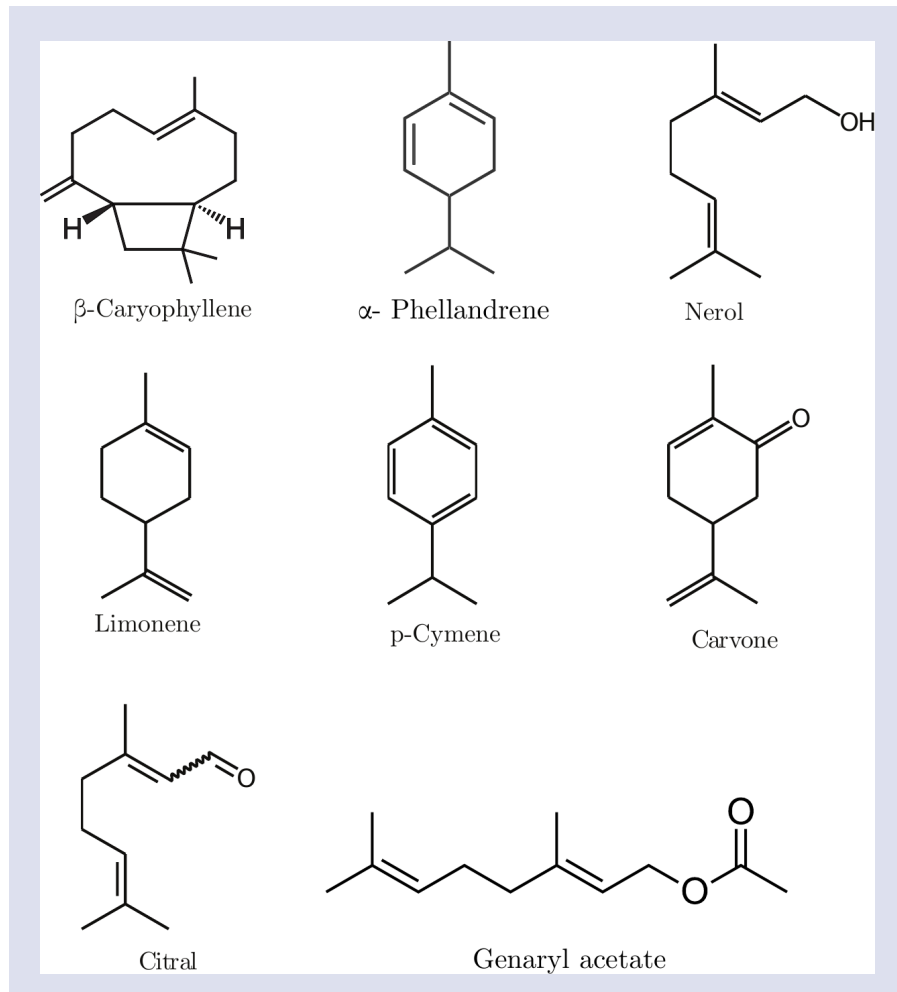

Figure 1: Structural formulas for the test essential oil compounds.

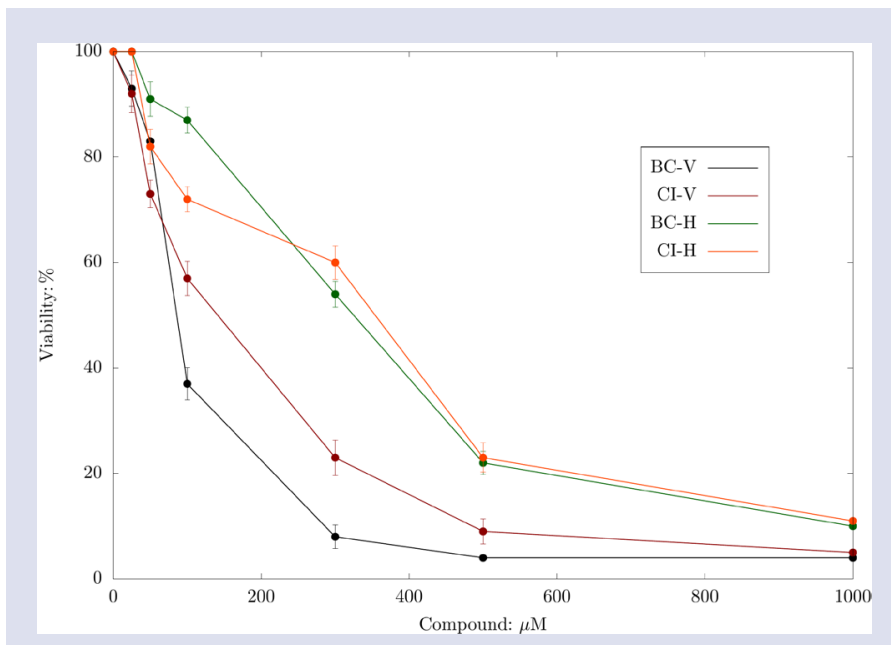

Figure 2: Representative dose response curves derived from MTT assays for evaluating of cytotoxicity. BC: $\beta$-caryophyllene. $\mathrm{Cl}$ : citral. V:Vero cells. H: HepG-2 cells. Data are mean \pm SD $(n=3)$.

MTT [3-(4, 5-dimethylthiazol-2-yl)-2, 5-diphenyltetrazolium bromide] solution $(5 \mathrm{mg} / \mathrm{mL})$ was added to each well. The extent of MTT reduction to formazan was quantified by measuring the OD. at $580 \mathrm{~nm}$ in a microplate reader (Multiskan Go, Thermo Fischer Scientific, USA). The half-maximal cytotoxic concentration $\left(\mathrm{CC}_{50}\right)$ for the compound with reference to untreated control cells which represented $100 \%$ cell viability, was defined as the concentration $(\mu \mathrm{M})$ that resulted in $50 \%$ cytotoxicity. Selectivity index (SI) is defined as the ratio of $\mathrm{CC}_{50}$ to $\mathrm{IC}_{50}$ values. 


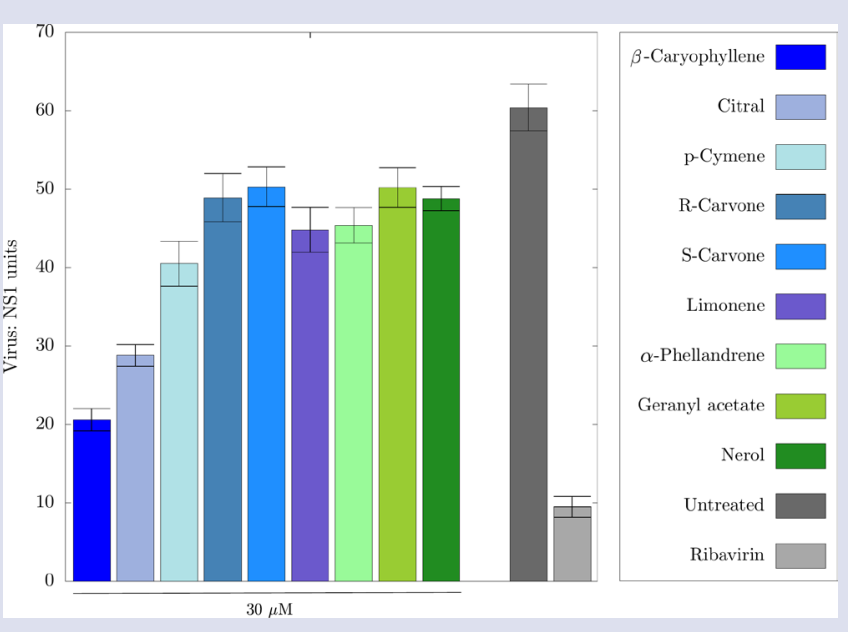

Figure 3: Antiviral activity of essential oil compounds against DENV-2 in the NS1 reduction assay. Ribavirin $(100 \mu \mathrm{M})$ was used as reference antiviral. Data are mean $\pm S D(n=2)$.

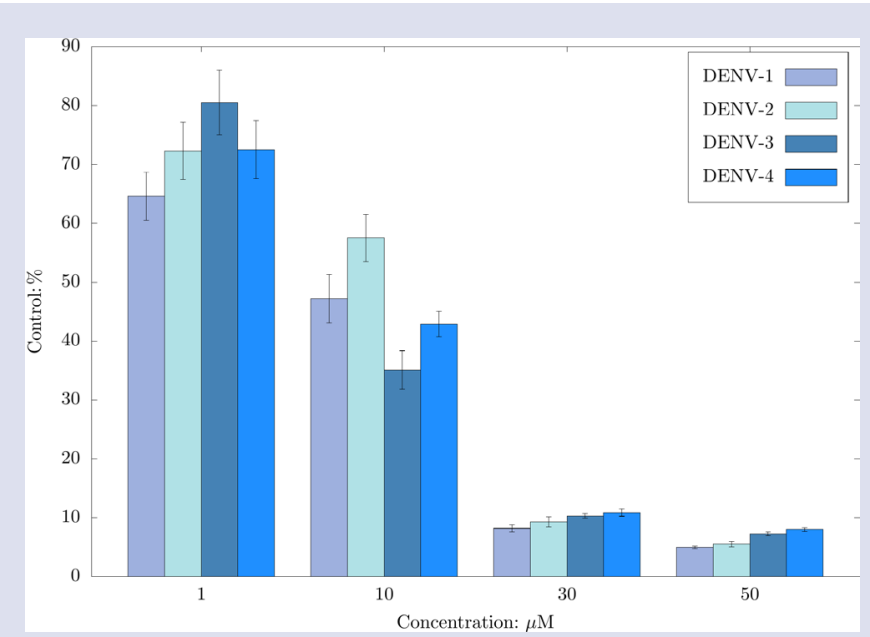

Figure 4: Antiviral activity of $\beta$-caryophyllene on dengue virus serotypes in the in situ cellular-ELISA assay. Data are mean $\pm S D(n=3)$, and are presented relative to OD $405 \mathrm{~nm}(100 \%)$ for untreated control cells.

Table 1: Antiviral activity of active terpenes on DENV-2 in the NS1 reduction assay.

\begin{tabular}{cccc}
\hline Terpene & $\mathrm{CC}_{50}: \mu \mathrm{M}$ & $\mathrm{IC}_{50} \mu \mathrm{M}$ & $\mathrm{IS}$ \\
\hline$\beta$-Caryophyllene & $380 \pm 25.4$ & $22 \pm 5.6$ & 17.2 \\
Citral & $490 \pm 10.2$ & $31 \pm 4.5$ & 15.8 \\
\hline
\end{tabular}

IS: selectivity index, Data are mean \pm DS $(n=3)$.

Table 2: Antiviral activity of $\beta$-Caryophyllene on dengue virus in the in-situ ELISA assay.

\begin{tabular}{ccccc}
\hline \multirow{2}{*}{ Activity } & \multicolumn{4}{c}{ Serotype } \\
\cline { 2 - 5 } & DENV-1 & DENV-2 & DENV-3 & DENV-4 \\
\hline $\mathrm{IC}_{50}: \mu \mathrm{M}$ & $9 \pm 1.5$ & $15 \pm 3.6$ & $8 \pm 3.4$ & $11 \pm 4.9$ \\
Selectivity index & 8.8 & 5.3 & 10 & 7.3 \\
\hline
\end{tabular}

$\mathrm{CC}_{50}: 80 \pm 9.9 \mu \mathrm{M}$. Data are mean $\pm \mathrm{DS}(\mathrm{n}=3)$.

\section{Data analysis}

All data were analysed using the R Project for Statistical Computing (R Development Core Team [2013]. R: A language and environment for statistical computing. R Foundation for Statistical Computing, Vienna, Austria. ISBN 3-900051-07-0, URL http://www.R-project.org). Data are shown as mean \pm standard deviation of independent experiments performed as duplicates or triplicates and are presented relative to untreated control cells.

\section{RESULTS}

All test compounds were screened initially for cytotoxicity in the MTT assay. Figure 2 presents representative curves dose response. Results showed that the compounds have not discernible toxicity at the maximum concentration $(100 \mu \mathrm{M}$ or $50 \mu \mathrm{M})$ used for evaluating of antiviral activities in HepG-2 and Vero cells. $\mathrm{CC}_{50}$ values for all nine compounds were higher than $79 \mu \mathrm{M}$ on both cell lines.

DENV directly invades and replicates in the liver during the acute course of natural infection. ${ }^{22}$ HepG-2 cells were designed to evaluate antiviral effect on DENV-2 of all selected compounds in the NS1 reduction assay. In order to select a compound as good virus inhibitor, it was reasoned that it must reduce NS1 protein close to $50 \%$ respect to untreated control by using maximum concentration of $30 \mu \mathrm{M}$. This concentration is within the effective concentration range of antiviral ribavirin in cellbased assays. ${ }^{23}$. The test compound was added after virus adsorption; thus, the assay revealed if the compound possessed the ability to inhibit post-entry steps in the virus life cycle.

NS1 reduction assays revealed two of nine compounds to possess inhibitory effect on DENV-2 at concentration of $30 \mu \mathrm{M}$ (Figure 3). $\beta$-caryophyllene reduced viral protein by $65 \%$ (21 \pm 3.5 units) and citral by $50 \%$ (30 \pm 3.4 units), relative to $100 \%$ ( $60 \pm 3.2$ units) in virus-infected untreated cells. Then, the terpenes were screened at concentration range, their $\mathrm{IC}_{50}$ values were less than $32 \mu \mathrm{M}$ and selectivity indexes were between 15 and 18 (Table 1 ). The remaining seven compounds ( $p$-cymene, limonene, a-phellandrene, nerol, R-carvone, S-carvone and geranyl acetate) did not reduce viral protein close to $50 \%$ at concentration of $30 \mu \mathrm{M}$. Thus, these compounds were scored as negative for antiviral effect and excluded from further analysis.

A good DENV inhibitor must be active against all four serotypes, and it should ideally have the potential to inhibit virus in any cell culture system. ${ }^{24} \beta$-Caryophyllene and citral were tested against all four serotypes at concentration range in the in situ cellular-ELISA assay. The antiviral action was based on reduction of cell-surface viral $\mathrm{E}$ protein expressed as $\mathrm{OD}_{405 \mathrm{~nm}}$ value respect to $100 \%$ of virus-infected untreated cells. Vero cells not virus-infected that were exposed to the maximum concentration $(50 \mu \mathrm{M})$ of terpene, showed $75-91 \%$ cell viability during entire time (five days) of experiments. $\beta$-Caryophyllene inhibited all four serotypes between $89-92 \%$ at $30 \mu \mathrm{M}$ (Figure 4 ): their IC $_{50}$ values were less than $16 \mu \mathrm{M}$ and selectivity indexes were between 5 and 10 (Table 2). Citral did not reveal antiviral effect at maximum concentration of $50 \mu \mathrm{M}$ : the reduction of $\mathrm{OD}_{405 \mathrm{~nm}}$ values in DENV-1, -2, -3 and - 4 infected-cells were, respectively, $24,3 \%, 9.8 \%, 2.4 \%$ and $45.0 \%$.

In an attempt to determine how long the addition of $\beta$-caryophyllene could be postponed before it lost its antiviral effect, the NS1 protein reduction assay was performed as follows: DENV-2 (MOI of 0.5) was adsorbed $1 \mathrm{~h}$ on cells, compound $(100 \mu \mathrm{M})$ was added immediately $(0 \mathrm{~h})$, $4 \mathrm{~h}$ and $8 \mathrm{~h}$ afterwards. The viral NS1 protein level was measured $72 \mathrm{~h}$ after virus adsorption, in virus-infected untreated cells it was $45 \pm 1.8$ units. $\beta$-Caryophyllene reduced viral NS1 protein by $88.8 \%$ when it was added at $0 \mathrm{~h}$ ( $5 \pm 2.6$ units) and $4 \mathrm{~h}$ ( $5 \pm 1.7$ units) whereas $55.5 \%$ (20 \pm 2.8 units) 
at $8 \mathrm{~h}$. According to the results, the antiviral effect of the terpene appears to be associated with interruption of early steps of the virus life cycle.

\section{DISCUSSION}

Outcome of DENV infection is associated to both plasma viremia and proinflammatory cytokines levels. ${ }^{25}$ It has suggested that reducing viral load and cytokines levels by therapy, could prevent or lessen the chances of patients progressing to severe disease. ${ }^{3,4}$ Owing to their antiviral and anti-inflammatory properties, ${ }^{17-19}$ terpenes could have strong potential for being used in the search of new drugs for dengue.

This study aimed to evaluate the antiviral activity in vitro of compounds found in essential oils with anti-dengue activity. It was began identifying the strongest compound against a single serotype, from nine selected for evaluation, by using a single concentration of $30 \mu \mathrm{M}$. At this concentration, it is expected that a lead compound for drug discovery should display an inhibition level of at least $50 \%$ without toxicity to cell. ${ }^{24}$ $\beta$-Caryophyllene and citral were identified as inhibitors of the DENV-2 replication. Then, the terpenes were evaluated against all four-virus serotype, and $\beta$-caryophyllene was identified as a pan-DENV inhibitor.

Two cell-based assays were developed to identify essential oils compounds with potential DENV-inhibitory effect. Since these compounds may be toxic to cells, it is important to use non-toxic concentrations to preserve cell viability, thereby allowing extensive viral replication. As results of MTT assays indicated, the test compounds exhibited maximum non-toxic concentration in both cell lines at level higher than maximum concentration used for antiviral screening. Observations on uninfected cells treated with compound at $100 \mu \mathrm{M}$ for three days (HepG-2 cells) or $50 \mu \mathrm{M}$ for five days (Vero cells), showed no changes in the normal state of cell monolayers throughout the antiviral test period. Therefore, the antiviral activity of compounds did not result from general cellular toxicity. The virus plaque assay, which is considered the reference test for screening, ${ }^{26}$ was not used to evaluate the anti-DENV activity of test compounds. Instead of this assay, two assays based on detection of the viral NS1 and E proteins were used. It has been demonstrated that after DENV adsorption on HepG-2 and Vero cells, both viral protein (E and NS1) and virus progeny are detected..$^{27,28}$ Moreover, simultaneous reduction of NS1 protein secretion and progeny virus production has been demonstrated in assays evaluating anti-dengue activity in vitro of compounds. ${ }^{29,30}$ Thus, the viral protein reduction caused by treatment with $\beta$-caryophyllene and citral indicated that viral progeny was also reduced. The cell-based assays were designed to identify compounds that had the ability to inhibit DENV within the cells. Therefore, virus adsorption preceded exposure to the compound. As virus was not incubated with compound before adsorption, virucidal activity was not evaluated.

An antiviral drug against dengue may be targeted against one or more of the key steps of the DENV life cycle to achieve effective reduction of viral progeny. ${ }^{24}$ To understand the mode of antiviral action of $\beta$-caryophyllene, time of addition experiments were carried out. It has been shown that one round of DENV life cycle in HepG-2 cells encompassed between 12-17 $\mathrm{h}$ after viral adsorption. ${ }^{27}$ More than one round of viral cycle was encompassed in the experiments testing $\beta$-caryophyllene, the NS1 protein was measured $72 \mathrm{~h}$ after viral adsorption. Even so, $\beta$-caryophyllene almost completely reduced the virus replication when it was added at time $(0 \mathrm{~h})$ and $4 \mathrm{~h}$ after viral adsorption but far less at $8 \mathrm{~h}$ afterwards. It is plausible that the terpene may interfere with virion envelope structures or mask membrane cellular components, which are required for adsorption and penetration of the virus into a host cell. It has been showed that $\beta$-caryophyllene and monoterpenes may inhibit enveloped viruses at early stage of the viral cycle. ${ }^{20,31,32}$ Moreover, $\beta$-caryophyllene is able to interact with artificial lipid bilayer. ${ }^{33}$ Citral reduced DENV-2 infection in the NS1 reduction assay in HepG-2 cells. Nevertheless, the same effect was not observed against this serotype and the others in the in-situ ELISA assay in Vero cells. An explanation for these conflicting results might be related to different conditions for the virus to replicate. Increased viral replication for five days in Vero cells instead of three days in HepG-2 cells could result in a gradual loss in the antiviral effect. Antiviral effect of citral has been identified in cells infected with other enveloped viruses (Yellow-Fever Virus and Herpes Simplex Virus) for two or three days. ${ }^{15,33}$

\section{CONCLUSION}

Natural product-based drug discovery remains as alternative in the search for drugs to combat causing-diseases viruses. The interest of pharmaceutical companies in natural products as a source of drugs has grown notoriously, mostly in low income countries. ${ }^{34}$ Essential oils can inhibit the DENV replication in vitro; thus, they offer a great opportunity to find novel compounds as starting points towards discovery of drug to treat dengue. This work has explored the potentials of synthetic-derived essential oils compounds to inhibit the DENV replication in vitro. $\beta$-Caryophyllene has demonstrated success in blocking replication of all four virus serotypes, making it a promising novel starting point for drugs discovery. $\beta$-Caryophyllene is a bicyclic sesquiterpene, it is a safe compound (GRAS) according to the Flavor and Extract Manufacturers Association (FEMA 2252) and the US Food and Drug Administration. ${ }^{35}$ The results of this study encourage further research about the potentials of $\beta$-caryophyllene and other terpenes as lead molecules for discovering of antivirals and immunosuppressant drugs for dengue.

\section{ACKNOWLEDGMENT}

The authors are grateful to Dr. Elizabeth Hunsperger (CDC, Puerto Rico) for sharing anti-dengue antibodies and her support for developing of the in-situ cellular ELISA assay. This work was carried out thanks to financial support received from Colombian Government - Grant RC-0572-2012 (Patrimonio Autónomo del Fondo Nacional de Financiamiento para la Ciencia, la Tecnología y la Innovación, Francisco José de Caldas).

\section{CONFLICT OF INTEREST}

No conflict of interest are declared.

\section{ABBREVIATION USED}

DENV: Dengue virus; DMSO: Dimethyl sulfoxide; MTT: 3-(4,5-dimethylthiazol-2-yl)-2,5-diphenyltetrazolium bromide). $\mathrm{CC}_{50}$ : Cytotoxic concentration 50; IC $_{50}$ : Inhibition concentration 50. IS: Index of selectivity.

\section{REFERENCES}

1. Mukhopadhyay S, Kuhn R, Rossmann M. A structural perspective of the flavivirus life cycle. Nat Rev Microbiol. 2005;3(1):13-22.

2. Shepard D, Undurraga E, Halasa Y, Stanaway J. The global economic burden of dengue: a systematic analysis. Lancet Infect Dis. 2016;16(8):935-41.

3. Chan C, Ooi E. Dengue: an update on treatment options. Future Microbiol. 2015;10(12):2017-31.

4. Lai J, Lin Y, Hsieh S. Pharmacological intervention for dengue virus infection. Biochem Pharmacol. 2017; 129:14-25.

5. Low J, Ooi E, Vasudevan S. Current status of dengue therapeutics research and development. J Infect Dis. 2017;215(suppl 2):S96-102. doi:10.1093/infdis/ jiw423.

6. Beesetti H, Khanna N, Swaminathan S. Investigational drugs in early development for treating dengue infection. Expert Opin Investig Drugs. 2016;25(9):1059-69.

7. Costa DSA, Teixeira R, Silva OA, Souza A, Silva M, Paula S. Review potential antivirals: natural products targeting replication enzymes of dengue and chikungunya viruses. Molecules 2017;22(3):505. doi:10.3390/molecules22030505.

8. Abd-Kadir S,Yaakob H, Mohamed-Zulkifli R. Potential anti-dengue medicinal plants: a review. J Nat Med. 2013;67(4):677-89. doi:10.1007/s11418-013-0767.

9. Abubakr M, Mandal S, Banerjee S. Natural compounds against flaviviral infections. Nat Prod Commun. 2013;8(10):1487-92.

10. Kumar S, Kumar S, Rehman I, Dhyani P, Kumari L, Achaira S, et al. Molecular 
herbal inhibitors of dengue virus: an unpdate. Int J Med Arom Plant. 2012;2(1):1-21.

11. Pandey K, Kumar P, Singh P, Tripathi N, Baipai V. Essential oils: sources of antimicrobials and food preservatives. Front Microbiol. 2017;7:2161. doi:10.3389/ fmicb.2016.02161.

12. García C, Acosta E, Carro A, Fernández M, Bomben R, Duschatzky C, et al. Virucidal activity and chemical composition of essential oils from aromatic plants of central west Argentina. Nat Prod Commun. 2010;5(8):1307-10.

13. Ocazionez R, Meneses R, Torres F, Stashenko E. Virucidal activity of Colombian Lippia essential oils on dengue virus replication in vitro. Mem Inst Oswaldo Cruz. 2010;105(3):304-9.

14. Meneses R, Ocazionez R, Martínez J, Stashenko E. Inhibitory effect of essential oils obtained from plants grown in Colombia on yellow fever virus replication in vitro. Ann Clin Microbiol Antimicrob. 2009;8(1):8. doi: 10.1186/1476-0711-8-8.

15. Gómez L, Stashenko E, Ocazionez R. Comparative study on in vitro activities of citral, limonene and essential oils from Lippia citriodora and L. alba on yellow fever virus. Nat Prod Commun. 2013;8(2):249-52.

16. Seow $Y$, Yeo $\mathrm{C}$, Chung $\mathrm{H}$, Yuk $\mathrm{H}$. Plant essential oils as active antimicrobial agents. Crit Rev Food Sci Nutr. 2014;54(5):625-44.

17. Barros AM, Castro ESJ, Rolim HM, Medeiros M, Cerqueira G, Castro A, et al. Diterpenes as lead molecules against neglected tropical diseases. Phytother Res. 2017;31(2):175-201.

18. Islam M, Mata A, Aguiar R, Paz M, Alencar M, Ferreira P, et al. Therapeutic potential of essential oils focusing on diterpenes. Phytother Res. 2016;30(9):1420-44

19. de Cássia da Silveira e Sá R, Andrade L, Sousa D. A review on anti-inflammatory activity of monoterpenes. Molecules. 2014;19(2):1459-80.

20. Zamora A, Edmonds J, Reynolds M, Khromykh A, Ralph S. The in vitro and in vivo antiviral properties of combined monoterpene alcohols against West Nile virus infection. Virology. 2016;495:18-32.

21. Vorndam V, Beltran M. Enzyme-linked immunosorbent assay-format microneutralization test for dengue viruses. Am J Trop Med Hyg. 2002;66(2):208-12

22. Rosen L, Drouet M, Deubel V. Detection of dengue virus RNA by reverse transcription-polymerase chain reaction in the liver and lymphoid organs but not in the brain in fatal human infection. Am J Trop Med Hyg. 1999;61(5):720-4.

23. Takhampunya R, Ubol S, Houng H, Cameron C, Padmanabhan R. Inhibition of dengue virus replication by mycophenolic acid and ribavirin. J Gen Virol. 2006;87(7):1947-52.

24. Botting C, Kuhn R. Novel approaches to flavivirus drug discovery. Expert Opin Drug Discov. 2012;7(5):417-28

25. Malavige G, Ogg G. Pathogenesis in vascualr leak in dengue virus infection Immunology. 2017;151(3):261-69.

26. Noble C, Chen Y, Dong H, Gu F, Lim S, Schul W, et al. Strategies for development of dengue virus inhibitors. Antiviral Res. 2010;85(3):450-62.

27. Suksanpaisan $L$, Susantad T, Smith $D$. Characterization of dengue virus entry into Hep G2 cells. J Biom Sci. 2009;16(1):17.doi:10.1186/1423-0127-16-17.

28. Chen Y, Maguire T, Hileman R, Fromm J, Esko J, Linhardt R, et al. Dengue virus infectivity depends on envelope protein binding to target cell heparan sulfate. Nat Med. 1997;3(8):866-71.

29. Alagarasu K, Patil $P$, Shil $P$, Seervi M, Kakade M, Tillu H, et al. In-vitro effect of human cathelicidin antimicrobial peptide LL-37 on dengue virus type 2. Peptides. 2017:92:23-30.

30. Bautista C, Soto R, Angel A, Cervantes M, Loranca C, Herrera M, et al. The calmodulin antagonist W-7 (N-(6-aminohexyl)-5-chloro-1-naphthalenesulfonamide hydrochloride) inhibits DENV infection in Huh-7 cells. Virology: 2017;501:188-98.

31. Astani A, Schnitzler P. Antiviral activity of monoterpenes beta-pinene and limonene against herpes simplex virus in vitro. Iran J Microbiol. 2014;6(3):149-55.

32. Astani A, Reichling J, Schnitzler P. Comparative study on the antiviral activity of selected monoterpenes derived from essential oils. Phytother Res. 2010; 24(5):673-9

33. Sarpietro M, Di Sotto M, Accolla M, Szumny A. Interaction of $\beta$-caryophyllene and $\beta$-caryophyllene oxide with phospholipid bilayers: differential scanning calorimetry study. Thermochim Acta. 2015;600:28-34.

34. David B, Wolfender J, Dias D. The pharmaceutical industry and natural products: historical status and new trends. Phytochem Rev. 2015;14(2):299-315.

35. Flavoring and Extract Manufacturers Association. FEMA Database: Beta-Caryophyllene (FEMA No. 2252). Washington, DC: Flavor and Extract Manufacturers Association. 1997.

Cite this article: Flechas MC, Ocazionez RE, Stashenko EE. Evaluation of in vitro Antiviral Activity of Essential Oils Compounds Against Dengue Virus. Pharmacog J. 2018;10(1):55-9. 